Archived version from NCDOCKS Institutional Repository - http://libres.uncg.edu/ir/asu/

Carmichael, S.K., Waters, J.A. Suttner, T.J., Kido, E., and DeReuil, A.A. (2014) A new model for the Kellwasser Anoxia Events (Late Devonian): Shallow water anoxia in an open oceanic setting in the Central Asian Orogenic Belt. Palaeogeography, Palaeoclimatology, Palaeoecology, 399: 394-403 (April 2014). Published by Elsevier (ISSN: 0031-0182).

http://dx.doi.org/10.1016/j.palaeo.2014.02.016. The version of record is available from:

www.elsevier.com

\title{
A new model for the Kellwasser Anoxia Events (Late Devonian): Shallow water anoxia in an open oceanic setting in the Central Asian Orogenic Belt
}

Sarah K. Carmichael, Johnny A. Waters, Thomas J. Suttner, Erika Kido, and Aubry A. DeReuil

\begin{abstract}
The Frasnian-Famennian mass extinction event devastated tropical marine ecosystems and ranks in the top six in taxonomic and ecological severity. The close stratigraphic association between the extinction and the Kellwasser Anoxia Events support a link between oceanographic anoxia and extinction. The Upper and Lower Kellwasser horizons have been identified in epicontinental and basinal settings in Laurussia, Gondwana, Siberia, and South China. The Hongguleleng Formation (Late Devonian) in northwestern Xinjiang, China, contains both the Frasnian-Famennian boundary and the rebound from the Frasnian-Famennian extinction event in a highly fossiliferous shallow marine setting associated with a Devonian oceanic island arc complex (part of the Central Asian Orogenic Belt, or CAOB). Here we show that the Hongguleleng Formation also records the Upper Kellwasser Anoxia Event through analysis of multiple geochemical proxies. In contrast to previous studies asserting that the Kellwasser Events were restricted to epicontinental seaways and basins, our results indicate that it occurred not only along the shallow continental margins of the closing Rheic Ocean, but also in shallow water in the open oceanic part of Paleotethys. Previous explanations for the Kellwasser Events from epicontinental margins and basins call for the migration of deep anoxic bottom water into shallow water environments as a kill mechanism for shallow marine ecosystems or attribute it to sea level rise and subsequent stagnation. There is no evidence that the Devonian oceans completely overturned during the Kellwasser Events; similarly, many transgressive events in the Devonian are not associated with black shales. We therefore suggest an alternative mechanism for the Kellwasser Events based on new evidence from the $\mathrm{CAOB}$, where anoxia is driven by episodic eutrophication of surface waters.
\end{abstract}




\section{INTRODUCTION}

The Devonian was a time of dynamic long-term climate change and substantial changes in biodiversity. Trees and seed plants produced the first multi-storied forests (Algeo and Scheckler, 1998). Coralstromatoporoid reef complexes flourished in the marine realm forming the most extensive reef constructions in Earth history (Copper, 2002). The rapid rise of land plants during the Middle Devonian was coupled with rapidly decreasing atmospheric $\mathrm{CO} 2$ values from $4000 \mathrm{ppm}$ to nearly present day values of about $350 \mathrm{ppm}$ during the latest Devonian (Royer, 2006). The successful coral-stromatoporoid reef ecosystem became extinct in the late Frasnian during the Frasnian-Famennian mass extinction event and was replaced by calcimicrobial reefs in the Famennian (Copper and Scotese, 2003). Taxonomic severity rankings of the 10 largest Phanerozoic biodiversity crises place the Frasnian-Famennian event at number six with a taxonomic loss of 35\% (Sepkoski, 1996 and McGhee et al., 2013). A new ecological severity metric ranks the Frasnian-Famennian event as the fourth most ecologically severe crisis in the Phanerozoic (McGhee et al., 2013). An alternate interpretation of the Frasnian-Famennian extinction suggests that a lack of origination rather than extinction caused the depletion in diversity (Bambach et al., 2004 and Stigall, 2012).

The Frasnian-Famennian extinction is stratigraphically associated with the Upper and Lower Kellwasser Anoxia Events, a pair of ocean anoxia events characterized by bituminous limestone or black shale sequences. The Kellwasser Events are associated with sustained or intermittent anoxia, enhanced productivity, and storm or tsunami deposits (Sandberg et al., 1988, Racki et al., 2002, Du et al., 2008 and Bond et al., 2013). Sea level oscillations, tectonic forcing, and ocean stratification have frequently been considered the primary drivers of the Kellwasser Events (Sandberg et al., 1988, Joachimski and Buggisch, 1993, McGhee, 1996, Chen et al., 2002, Bond et al., 2004, Tribovillard et al., 2004, Bond and Wignall, 2008 and Chen et al., 2013), although when taken together these proposed mechanisms for anoxia development are somewhat contradictory and are dependent on local topography or tectonic forcing (Racki, 2005). Other factors such as eutrophication (Algeo and Scheckler, 1998, Murphy et al., 2000, Racki et al., 2002, Tribovillard et al., 2004 and Kazmierczak et al., 2012), or forest fires and subsequent soil erosion (Kaiho et al., 2013) have also been implicated as causal factors. The intensity and extent of anoxia during the two Kellwasser Events have been investigated in localities on Laurussia, Gondwana, Siberia, and South China (Joachimski and Buggisch, 1993, Bond et al., 2004, Tribovillard et al., 2004, Bond and Wignall, 2005, Pujol et al., 2006, Bond et al., 2013 and Chen et al., 2013). The Upper Kellwasser Horizon developed in the Late linguiformis Zone (Frasnian Stage) as an event that intensified anoxia in basinal locations and spread dysoxic waters into shallow water locations ( Bond et al., 2004 and Bond et al., 2013). Of sections spanning the Frasnian-Famennian boundary in Europe, only the continental margin of Austria was spared the Late Devonian anoxia ( Bond et al., 2004). As a 
result, the Upper Kellwasser Anoxia Event has been interpreted as an epicontinental seaway event rather than an 'oceanic' anoxic event that has spilled laterally onto continental shelf settings ( Bond et al., 2004 and Bond et al., 2013). In this study we are examining the Frasnian-Famennian boundary in a fundamentally different tectonic and depositional setting, in an open ocean island arc complex in the Central Asian Orogenic Belt (CAOB).

\section{REGIONAL GEOLOGY OF THE CAOB IN NORTHWESTERN CHINA}

The $\mathrm{CAOB}$, a complex amalgamation of intra-oceanic island arcs and continental fragments, was formed prior to the end of the latest Carboniferous (Xiao et al., 2010, Choulet et al., 2012 and Yang et al., 2013). Middle and Late Devonian sediments in Xinjiang, China, include the Zhulumute and Hongguleleng Formations, which formed as part of an accretionary wedge deposited on a Marianas Island type island arc complex (Fig. 1) (Suttner et al., 2014). This is one of the few Famennian localities in the world with richly fossiliferous sedimentary rocks deposited in a shallow marine, orogenic setting (Lane et al., 1997, Xia, 1997, Ma et al., 2011 and Suttner et al., 2014) (Fig. 2).

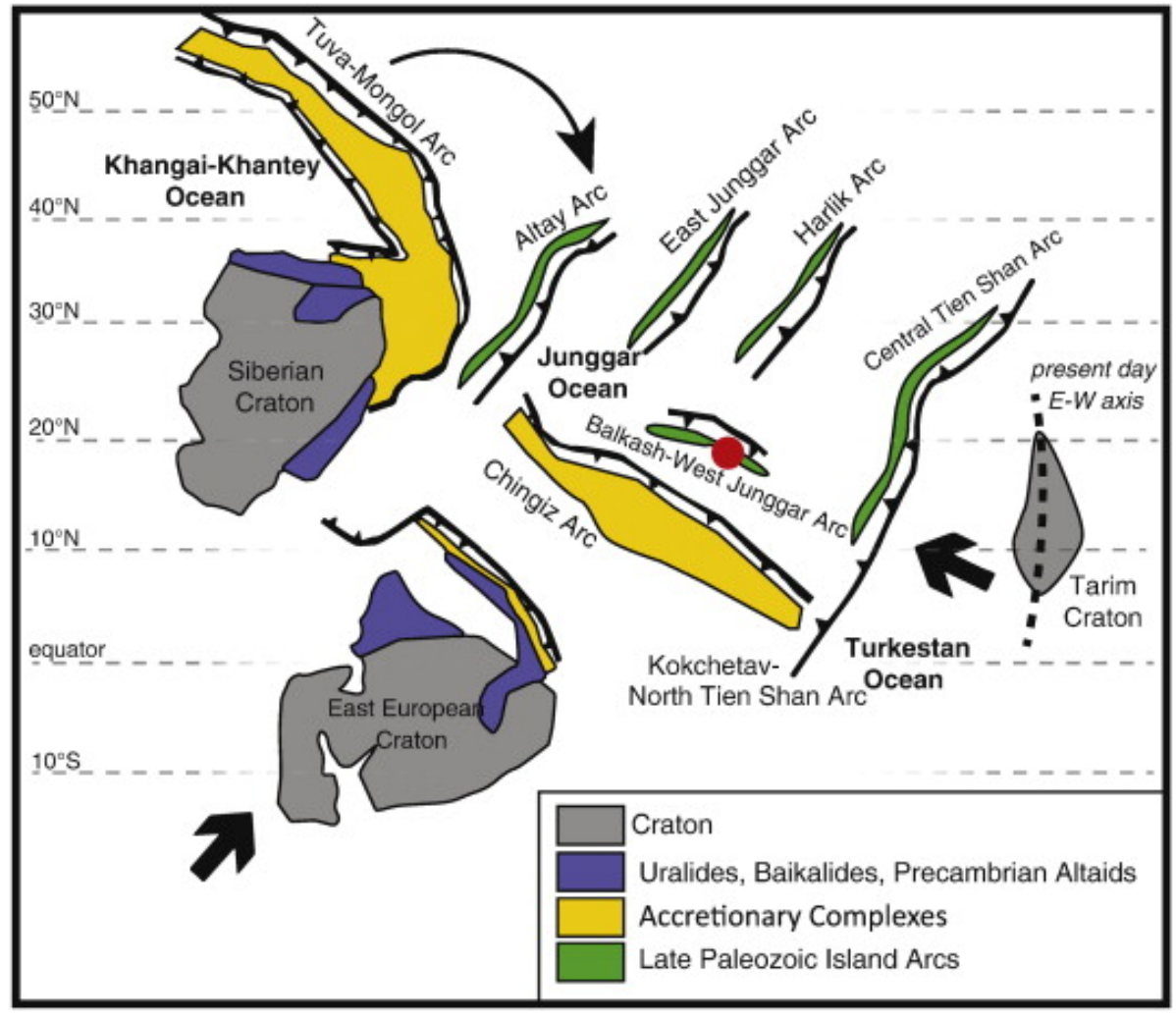

Fig. 1.

The Hongguleleng and Zhulumute Formations (red dot) were deposited on the Balkash-West Junggar Arc, a Marianas type island arc complex, in one of the proposed tectonic models. Modified from Xiao et al., 2010. 


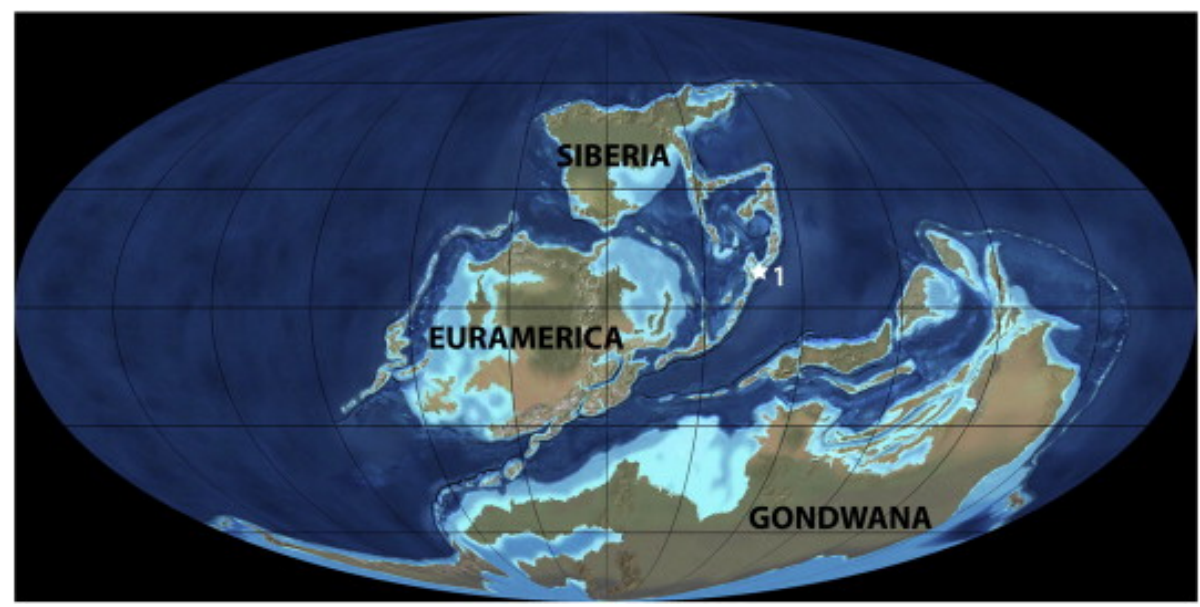

Fig. 2.

Paleogeography of Late Devonian (Blakey, 2008) with the Hongguleleng and Zhulumute Formations denoted with $\star 1$.

From 2005 to 2011, our research group measured a bed-by-bed stratigraphic section of the Hongguleleng Formation in several locations, including the Boulongour Reservoir section (Lane et al., 1997 and Suttner et al., 2014). The Frasnian-Famennian boundary is contained within the lower $3 \mathrm{~m}$ of the Hongguleleng Formation at the Boulongour Reservoir section (Fig. 3) (Suttner et al., 2014). Initial, exploratory work suggested the presence of a $\delta 13 \mathrm{C}$ excursion within the expected interval of the Kellwasser Event in the latest Frasnian at the Boulongour Reservoir section ( Suttner et al., 2014), although there were concerns about isotopic overprinting via fluid flow along a small ( $<2 \mathrm{~m}$ offset) fault at the base of the section. Additional samples in the interval straddling the Frasnian-Famennian boundary were collected in 2011 to completely delineate isotopic and geochemical changes occurring at the Frasnian-Famennian boundary, which could be correlated with the Kellwasser Event. 


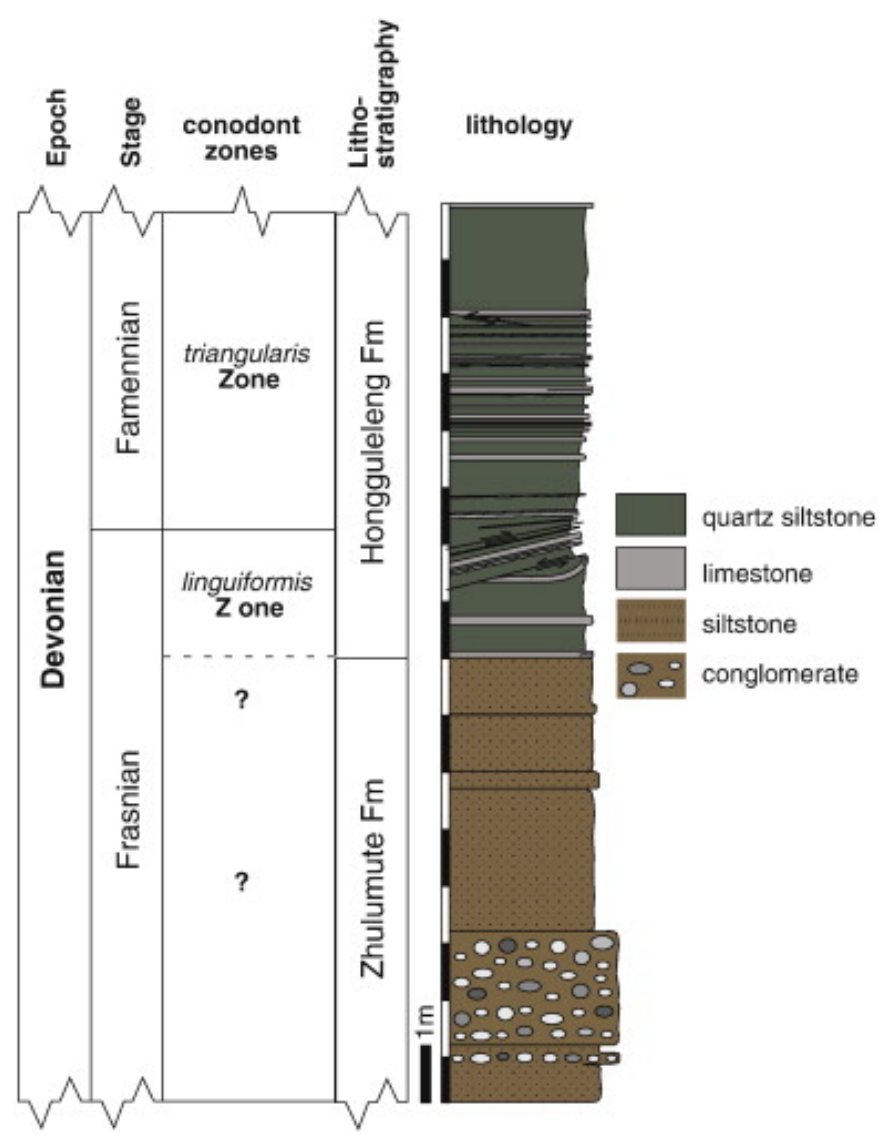

Fig. 3.

Stratigraphic column of the boundary interval of the Hongguleleng and Zhulumute Formations. After Suttner et al. (2014).

\section{MATERIALS AND METHODS}

\subsection{Geochemistry and microscopy}

Samples were analyzed for major, trace, and rare earth elements, stable isotopes of carbon and oxygen, mineralogy and mineral textures, and magnetic susceptibility. Unless otherwise noted, all analyses were performed at Appalachian State University. Whole rock geochemical analyses for both limestones and siltstones were performed by Activation Laboratories (Ancaster, ON, Canada), while all carbon and oxygen stable isotope analyses on brachiopods and/or micrite were performed using a Finnigan Delta Plus 230 isotope-ratio mass spectrometer (Institute for Earth Sciences, Graz, Austria). Magnetic susceptibility measurements were performed on a Bartington Instruments MS-3 meter with a dual frequency MS2B sensor. Microtextures and mineral morphologies were imaged and analyzed using cathodoluminescence (CL), scanning electron microscopy with energy dispersive X-ray spectroscopy (SEM-EDS), and SEM-cathodoluminescence (SEM-CL). SEM-EDS and SEM-CL 
analyses were performed on a FEI Quanta 200 environmental scanning electron microscope with an attached EDAX energy-dispersive X-ray spectrometer and a Centaurus $C L$ detector. CL imaging was performed on a RELIOTRON system. Bulk mineralogy was measured with a Shimadzu XRD 6000 X-ray diffractometer and was confirmed using SEM-EDS analysis.

\section{RESULTS AND DISCUSSION}

\subsection{Stratigraphy}

The stratigraphy of the Hongguleleng Formation and the overlying 'Hebukehe' and basal Heishantou Formations are discussed in detail in Suttner et al. (2014); in this study we consider only the lower $7 \mathrm{~m}$ of the more than $200 \mathrm{~m}$ of section, which represents a transgressive sequence from a beach deposit (upper Zhulumute Formation) to a shallow marine sequence (lowermost Hongguleleng Formation). In the Hongguleleng Formation, the Frasnian-Famennian boundary interval is a series of siltstones and limestones, but black shales are lacking (Fig. 3 ). Detailed sampling at $\sim 10 \mathrm{~cm}$ intervals was conducted from $1 \mathrm{~m}$ below the base of the Hongguleleng Formation (defined as the lowermost limestone unit) into the Zhulumute Formation. Although previous studies had suggested the presence of an unconformity between the Hongguleleng Formation and the underlying Zhulumute Formation (Ma et al., 2011), no evidence for an unconformity was observed in the field. Because the most recent conodont data defined the Frasnian-Famennian boundary as $2.4 \mathrm{~m}$ above the basal limestone unit (Suttner et al., 2014), detailed sampling continued through the lowermost 6 $\mathrm{m}$ of the section.

\subsection{Sedimentology}

Primary mineralogy in the basal Hongguleleng and uppermost Zhulumute Formations includes calcite, albite, and quartz, with minor chlorite and illite clays and trace Ti-oxides and apatite (Fig. 4). The part of the Zhulumute Formation considered herein is primarily composed of porphyritic basalt pebbles and detrital albite sand (Fig. 5), and grades upward to silt-sized particles of albite, chlorite, illite, and quartz approximately $1 \mathrm{~m}$ below the base of the Hongguleleng Formation (Suttner et al., 2014). The presence of porphyritic basalt pebbles and angular albite grains (with minor plant fossils) within the majority of the Zhulumute Formation indicates that the base of the Boulongour Reservoir section is analogous to a shoreline environment on an island arc rather than on a continental margin. Sediment source can be further constrained with whole rock Th/U ratios (Carpentier et al., 2013). Th/U of $\sim 3$ in the siliciclastic fraction of both units likewise indicates a juvenile sediment source such as an island arc (Fig. 6), which is consistent with previous studies on the tectonics of the region (Xiao et al., 2010, Choulet et al., 2012 and Yang et al., 2013). 


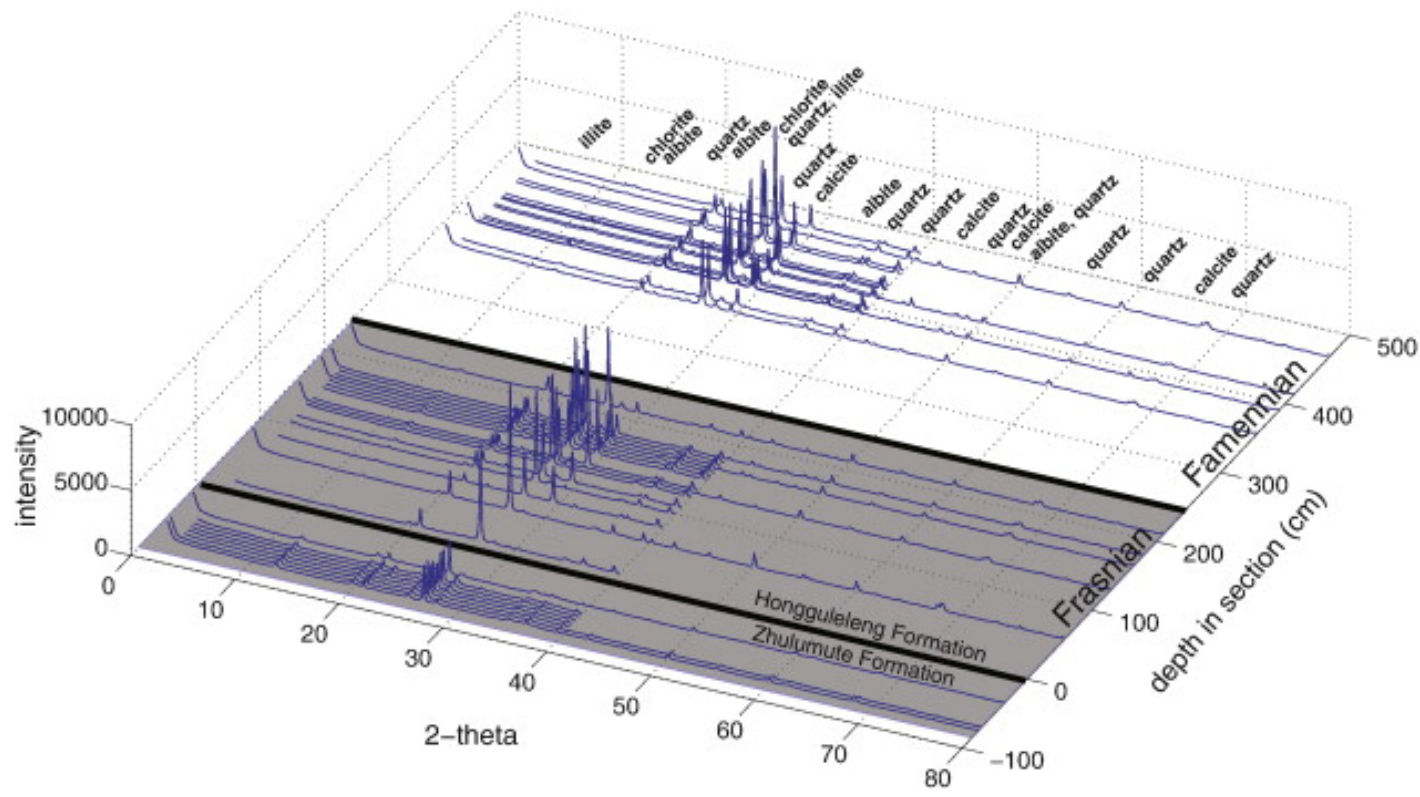

Fig. 4.

Bulk X-ray diffraction signatures of siliciclastic sediments in the topmost Zhulumute Formation and the lower Hongguleleng Formation. Minerals present are labeled next to their corresponding X-ray peaks. X-ray diffraction signatures across the Zhulumute-Hongguleleng contact and across the Frasnian-Famennian boundary show no changes in sedimentation aside from the amount of calcite present, indicating that sedimentation was continuous across both intervals. This is consistent with field observations that no unconformity is present across these intervals. 


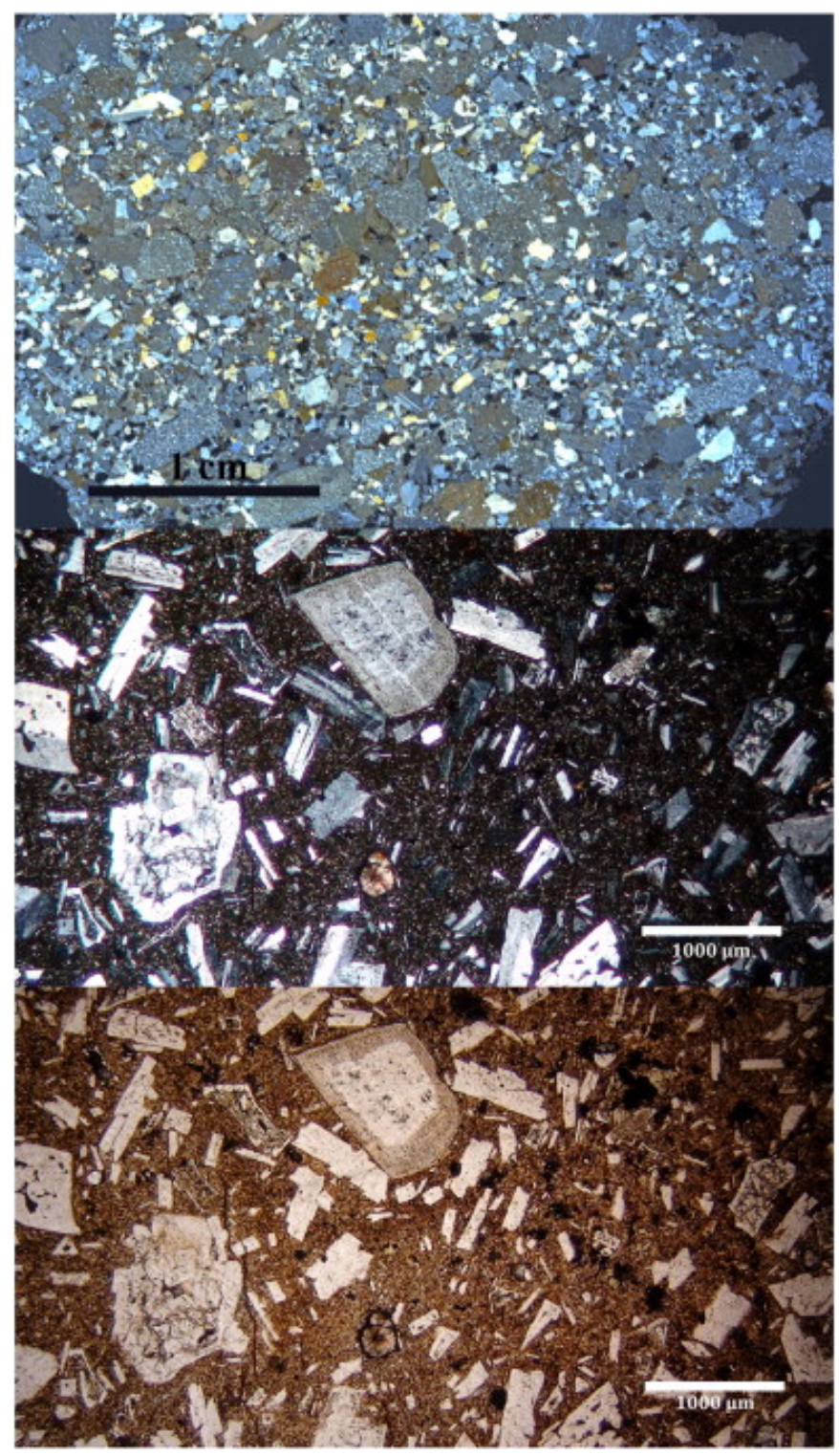

Fig. 5.

High resolution, high contrast photograph of Zhulumute Formation conglomerate sample (top) showing subhedral grains of albite with round pebbles of porphyritic volcanic rock; cross polarized (middle) and transmitted light (lower) microscopy photomicrograph of a porphyritic basalt pebble from the Zhulumute Formation conglomerate. 

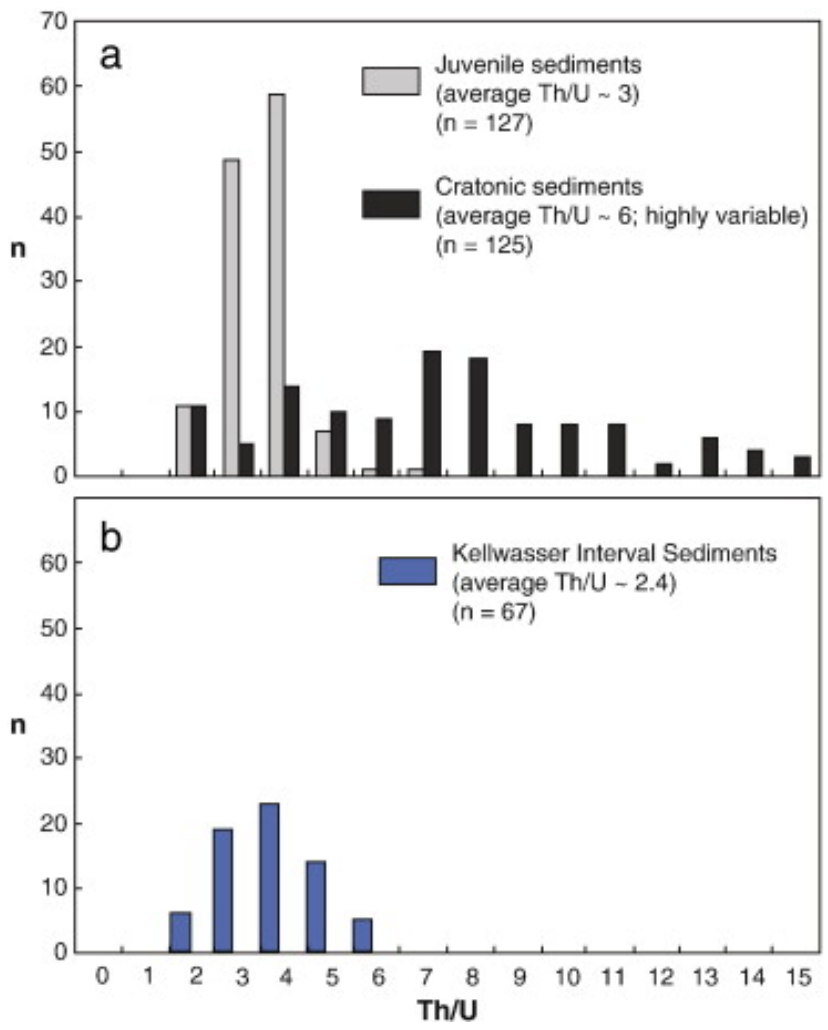

Fig. 6.

(a) Th/U ratios in modern sediments showing sedimentary provenance, where clustered $\mathrm{Th} / \mathrm{U}$ ratios $\sim 3$ indicate a juvenile sediment source (after Carpentier et al., 2013), in comparison to more mature cratonic sediments which have higher average Th/U ratios $(\sim 6)$ with more variability. (b) Th/U ratios in the Kellwasser Horizon at the Zhulumute-Hongguleleng Formation boundary cluster $\sim 2.4$, indicating a juvenile sediment source, consistent with an island arc.

There is no change in siliciclastic mineralogy across the ZhulumuteHongguleleng contact nor is there a change in siliciclastic mineralogy across the Frasnian-Famennian boundary (Fig. 4). Variations in the amount of calcite are primarily due to autochthonous brachiopod-rich storm deposits (Fig. 7). The uniform mineralogy across these units and across the Frasnian-Famennian boundary, combined with field observations in a trench we dug through the interval suggest that sedimentation was continuous throughout the interval, and that no significant unconformity is present, in contrast to previous work (Ma et al., 2011). 


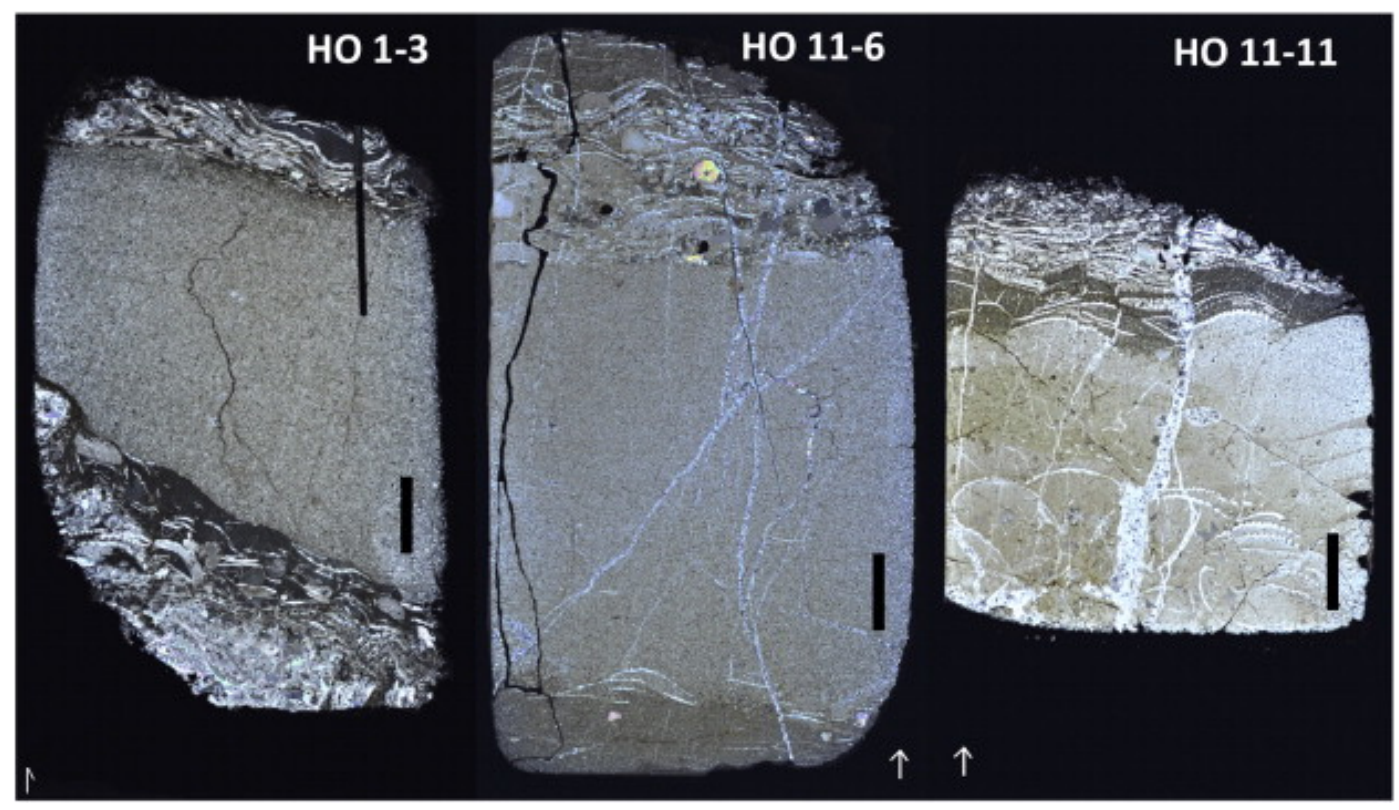

Fig. 7.

Storm deposits are associated with the Kellwasser Events in many localities. These three samples show concentrations of brachiopods that we interpret as storm deposits in the basal Hongguleleng Formation. H01-3 is Frasnian in age. H011-16 and 11-11 are Famennian in age. Images are thin sections photographed on a light table with cross polarized light using HDR imaging. Black scale bars are $5 \mathrm{~mm}$.

\subsection{Geochemical and mineralogical redox proxies}

Analysis of $\delta^{13} \mathrm{C}$ from the initial group of samples collected in 2005 showed a prominent 4\%o PDB negative excursion across the Frasnian-Famennian boundary ( Suttner et al., 2014), which is inconsistent with the positive $\sim 2 \%$ excursions seen in the Kellwasser Interval ( Joachimski et al., 2002, Racki et al., 2002, Bond et al., 2004, Buggisch and Joachimski, 2006 and Chen et al., 2013). Additional detailed sampling in 2011 at the base of the Hongguleleng shows a $5.5 \% \circ \delta^{13} \mathrm{C}$ negative excursion in the bottom $5 \mathrm{~m}$ of the Hongguleleng Formation, and oxygen isotopes $\left(\delta^{18} \mathrm{O}\right)$ values decrease by nearly $12 \%$ PDB compared to overlying $20 \mathrm{~m}$ of section ( Fig. 8). CL microscopy and SEM-EDS were used to assess the extent of alteration in samples in the bottom $5 \mathrm{~m}$ of the section. By identifying the altered samples, which have anomalously low $\delta^{18} \mathrm{O}$ and $\delta^{13} \mathrm{C}$ values (presumably due to meteoric water infiltration along the small fault at the base of the section in Fig. 3), we can construct a 2\%o positive $\delta^{13} \mathrm{C}$ excursion associated with the Kellwasser Event in the remaining unaltered samples, similar to what has been shown in the studies listed herein. The observed overprinting is unlikely to affect the other geochemical proxies used in this study, as the regionally available fluids which would exhibit the $\delta^{13} \mathrm{C}$ and $\delta^{18} \mathrm{O}$ overprinting signatures seen at the base of the section would not contain significant amounts of the chalcophile and heavy elements used as anoxia proxies ( Carmichael and Ferry, 2008 and references therein). 

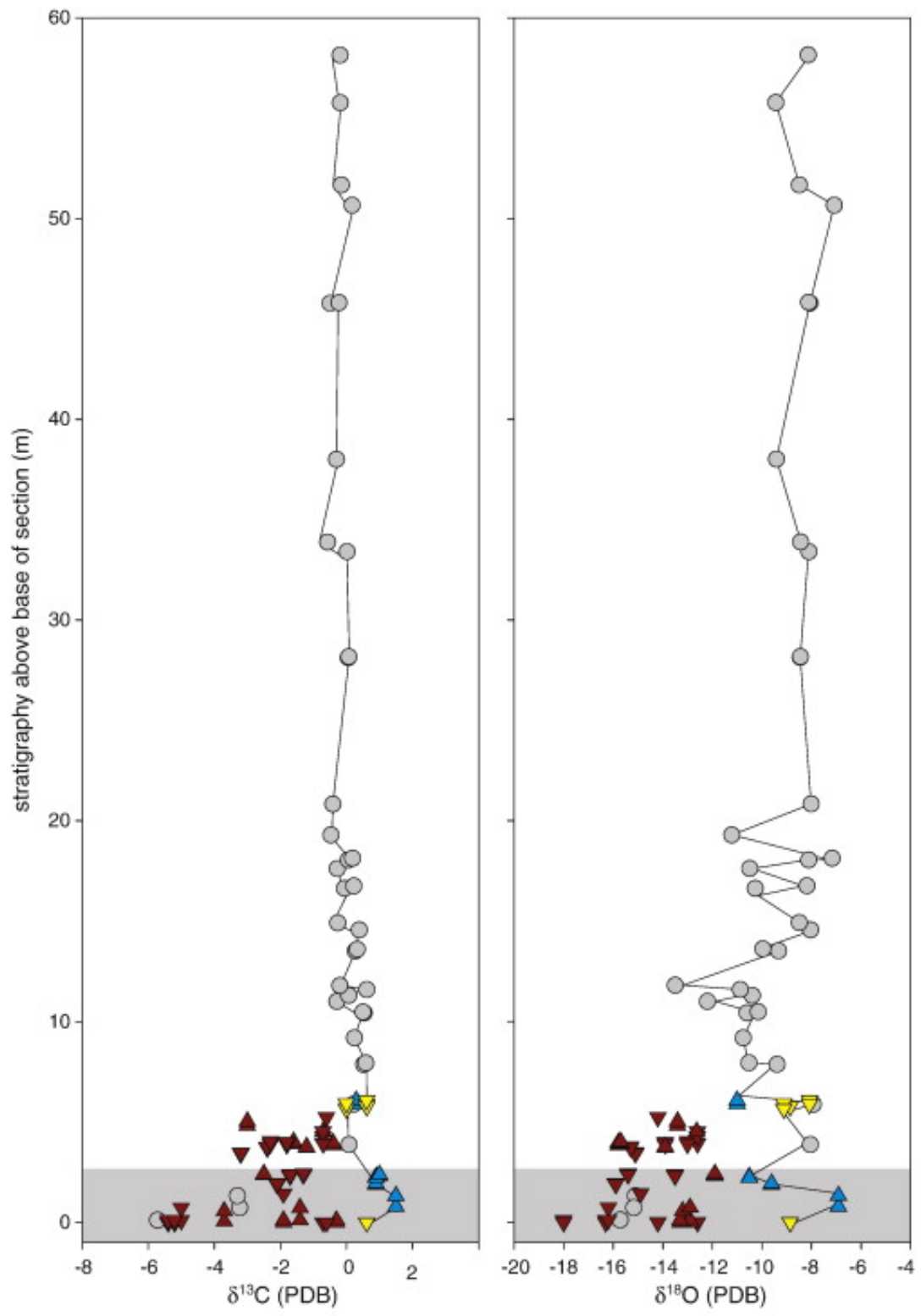

$\Delta$ brachiopod-minimal alteration

$\nabla$ micrite - minimal alteration

data from Suttner et al. (2014)

$\Delta$ brachiopod-significant alteration

micrite - significant alteration

Kellwasser Event

Fig. 8.

$\delta^{13} \mathrm{C}$ excursion at the base of the Hongguleleng Formation extending to $5 \mathrm{~m}$ above the base. Negative excursions in $\delta^{13} \mathrm{C}$ are inconsistent with other published studies of the Kellwasser Event (Joachimski et al., 2002, Racki et al., 2002, Bond et al., 2004, Buggisch and Joachimski, 2006 and Chen et al., 2013). $\Delta^{18} \mathrm{O}$ values also show a negative excursion, extending to $20 \mathrm{~m}$ above the base of the section. Triangles represent data from this study (brachiopods and micrite), where gray circles indicate data from Suttner et al. (2014). The expected location of the Upper

Kellwasser Anoxia Event is shown in gray. Samples in this study that were strongly overprinted by diagenetic alteration (as determined by a combination of CL microscopy, SEM-EDS imaging, $\mathrm{Mn}$ content, $\mathrm{Sr}$ content, and extremely negative $\delta^{18} \mathrm{O}$ values) are shown in brown. When altered samples are removed, there is a small positive $\sim 2 \% \delta^{13} \mathrm{C}$ excursion, which is consistent with other aforementioned studies of the Kellwasser Events. 
Multiple geochemical proxies suggest that oxygenation levels varied from oxic to anoxic near the Frasnian-Famennian boundary (Fig. 9). Both total vanadium content (Tribovillard et al., 2006) and V/Cr ratios (Schröder and Grotzinger, 2007) have been used to assess redox conditions. Because of low values of $\mathrm{Cr}$ in these samples (see supplemental dataset), 1/2 of the detection limit is used for $\mathrm{Cr}$ values below detection limit. $V$ values peak at $\sim 200 \mathrm{ppm}$ near the top of the Zhulumute Formation (Fig. 9), which is significantly above the average values of V ( $100 \mathrm{ppm})$ found in anoxic sediments (Schröder and Grotzinger, 2007). The $U$ content of sediments is a combination of authigenic and detrital components whereas the Th content is entirely detrital. Authigenic uranium is calculated as Uaut $=$ Utot $-\mathrm{Th} / 3$, with $\mathrm{Th} / 3$ as an estimate of the detrital uranium fraction in mudstones (Wignall and Myers, 1988). The spike in authigenic $U$ in the upper part of the Zhulumute Formation and the lower part of the Hongguleleng Formation supports the hypothesis of dysoxic to anoxic conditions in the Frasnian-Famennian boundary interval. Additional support comes from the elevated concentrations of redox sensitive elements such as $\mathrm{Zn}$, which are also used herein (in limestones) to assess oxygenation levels (Bond et al., 2004 and Pujol et al., 2006). Ce anomalies are calculated using Ceanom $=$ Log [3Cen / $(2 \mathrm{Lan}+\mathrm{Ndn})]$ (Wright et al., 1987), where " $\mathrm{n}$ " indicates REE normalization to the North American Shale Composite (NASC). Negative Ce anomalies are also present at the base of the Hongguleleng Formation, indicating that conditions are anoxic or approach anoxia. Although Mo is a commonly used proxy for anoxia in basinal black shales (Tribovillard et al., 2006), detectable Mo concentrations require long-term euxinic conditions (Algeo and Maynard, 2004) in a restricted basin environment (Algeo and Lyons, 2006). We do not detect Mo in any of the Boulongour Reservoir section samples as all of our other evidence for anoxia suggests fluctuating dysoxic to anoxic conditions rather than persistent euxinic conditions. As the Boulongour Reservoir does not have a black shale facies and is not part of a restricted basinal environment, nor is there any other geochemical or mineralogical evidence for persistent euxinic conditions anywhere in the section, the lack of detectable Mo is not unexpected. 

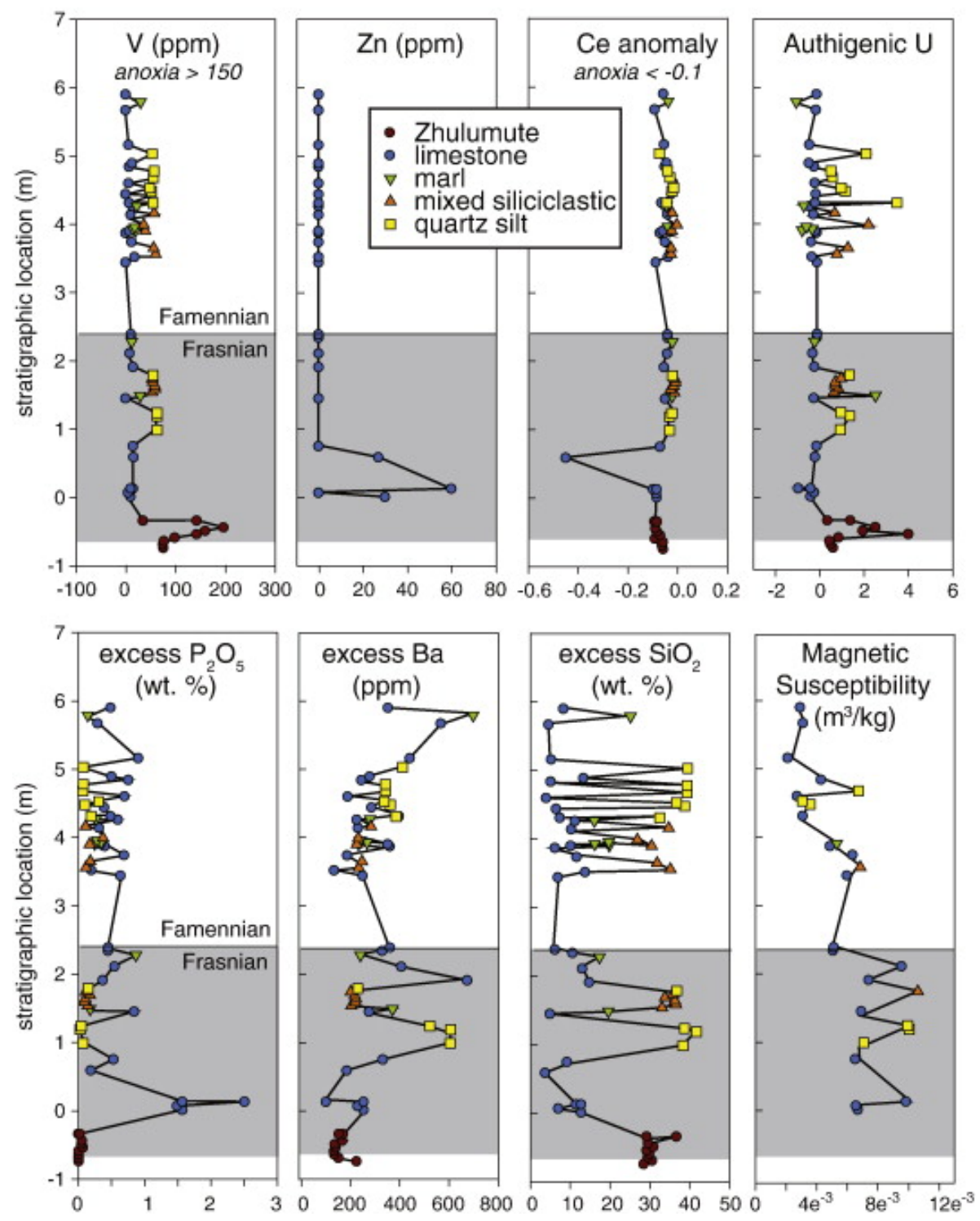

Fig. 9.

Geochemical anoxia proxy signatures in the topmost Zhulumute and basal Hongguleleng Formations. The Kellwasser interval is shown in gray with the Frasnian-Famennian boundary located $2.4 \mathrm{~m}$ above the base of the Hongguleleng Formation (see Fig. 3 for relation to stratigraphic section). Although the Kellwasser Event (shaded interval) cannot be detected visually by a change in mineralogy, it can be detected by geochemical proxies such as $V / C r$ ratios in siliclastics, $\mathrm{Zn}$ concentrations in carbonates, $\mathrm{Ce}$ anomalies in phosphate-rich units, and authigenic $U$ content in siliciclastics (Pujol et al., 2006 and Tribovillard et al., 2006). Excess whole rock $\mathrm{P} 2 \mathrm{O} 5, \mathrm{Ba}$, and $\mathrm{SiO} 2$ (Pujol et al., 2006) indicate increased primary productivity in the aftermath of anoxia. Magnetic susceptibility (MS) shows a distinct negative trend, which starts just below the Frasnian-Famennian boundary and is consistent with sea level rise associated with the Kellwasser Event. 
Pyrite framboids, a circular aggregate of pyrite microcrysts (Fig. 10), can also be used to assess redox conditions (Wilkin et al., 1996). Euxinia produces populations of tiny framboids $(<5 \mu \mathrm{m})$ with a narrow size range. In contrast, in dysoxic environments, size is largely governed by the local availability of reactants and the framboids are larger and more variable in size $(5-15 \mu \mathrm{m})$. Samples from the latest Frasnian contain pyrite framboids that are variable in size but are typically in the range of 5 to $15 \mu \mathrm{m}$ suggesting that the samples were formed in an anoxic to lower dysoxic environment (Fig. 11). The few samples containing framboids in the lower Famennian have framboids that are typically larger, and indicate that upper dysoxic to oxic conditions dominated (Bond and Wignall, 2010). Samples without framboids are assumed to be deposited under fully oxic conditions. The framboid data support interpretations of oxygen levels from the elemental geochemical data. Iron oxide framboids and spheres are also present in samples from the anoxia interval (Fig. 10), which is consistent with microbial fixation of $\mathrm{Fe} 2+$ during nitrate reduction in anoxic sediments (Chaudhuri et al., 2001), and/or with the subsequent oxidation of existing pyrite framboids (Suk et al., 1990). 

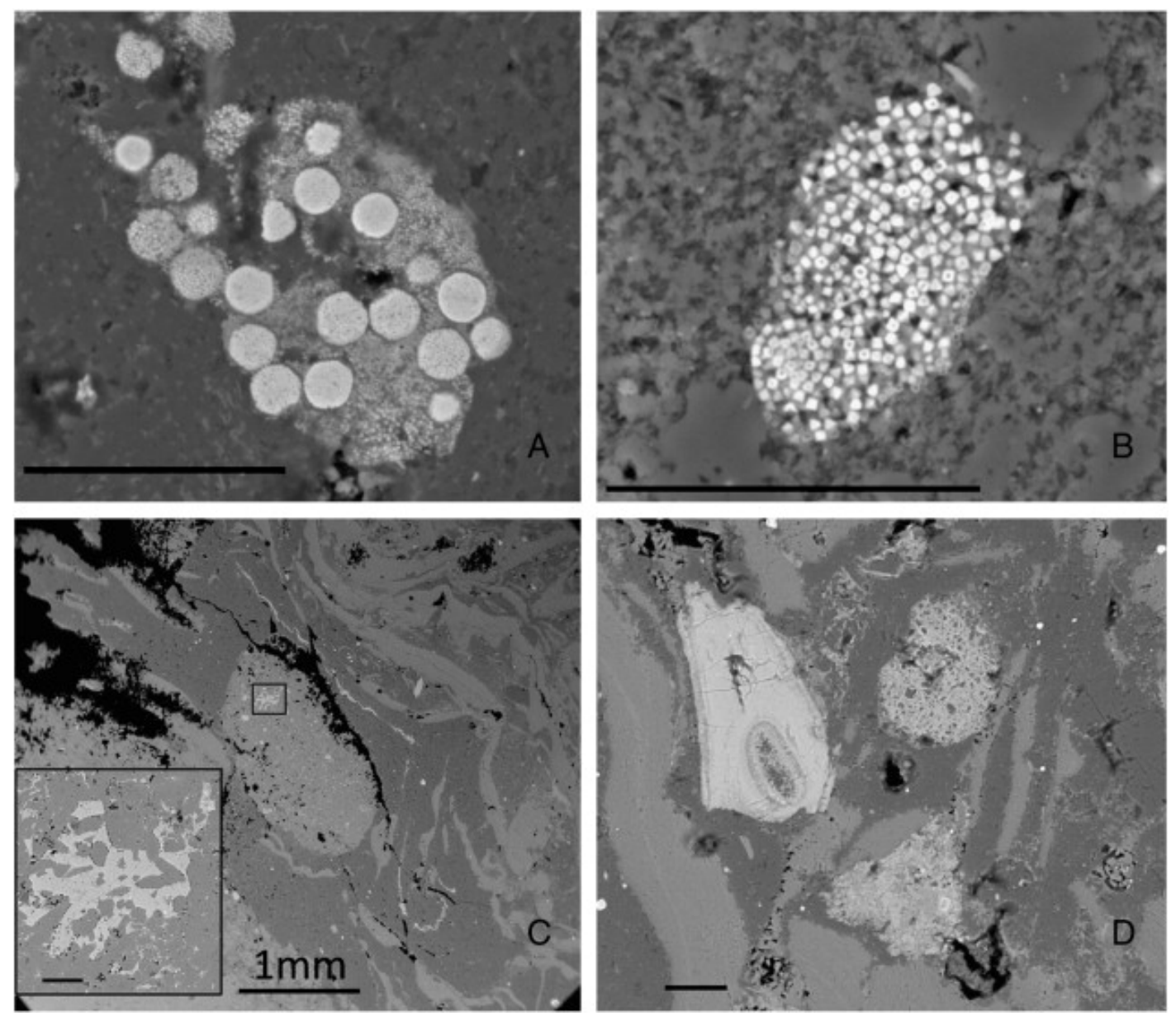

Fig. 10.

Backscattered scanning electron microscope photomicrographs of $(A)$ Late Frasnian pyrite framboids from $0.74 \mathrm{~m}$ above the base of the Hongguleleng Formation; (B) lower Famennian Fe oxide aggregates from $4.0 \mathrm{~m}$ above the base of the Hongguleleng Formation; (C) pore-filling apatite (light gray color) in pore spaces between brachiopod shells and filling voids in peloid interiors (inset box), indicating a non-detrital dissolved phosphate source within the water column; and (D) microbially mediated apatite (light gray, porous grains in the top right and center bottom), in contrast to a broken conodont in the top left. Scales are $50 \mu$ except as noted. 


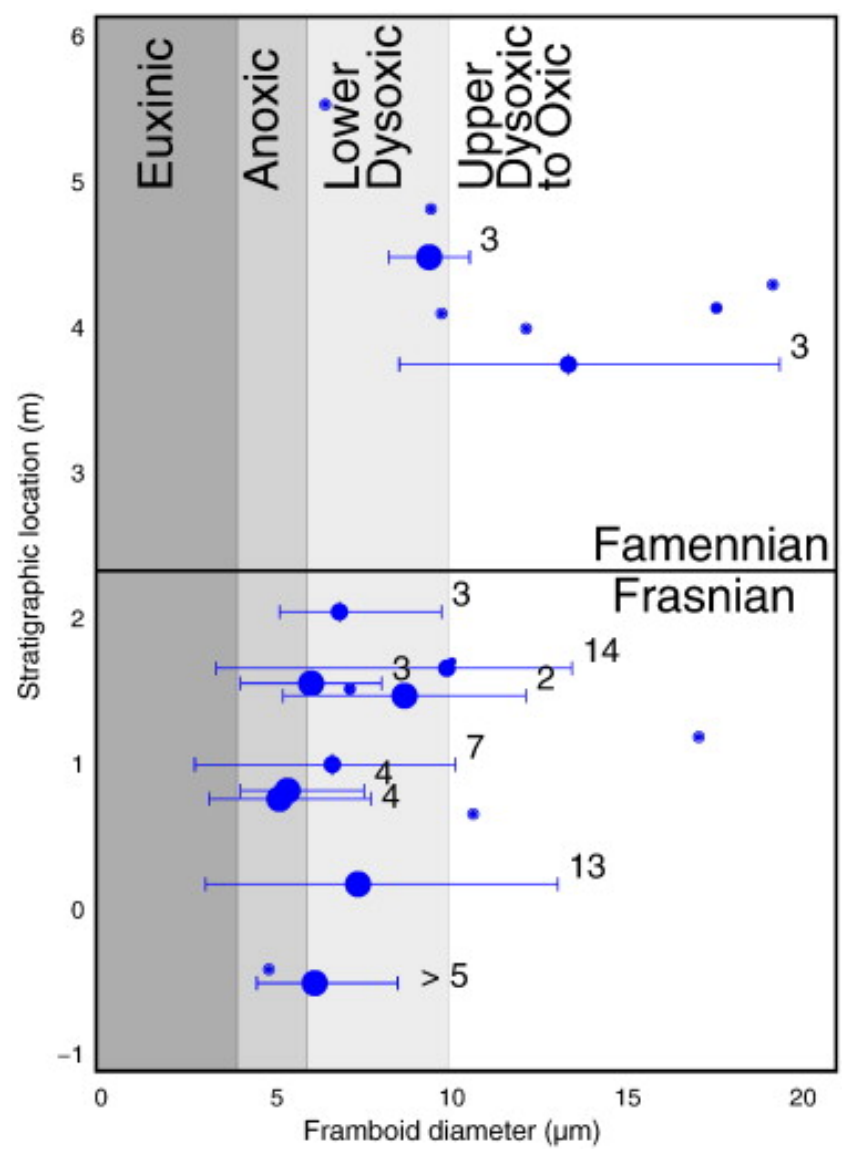

Fig. 11.

The size and variability of pyrite framboids can be used to assess redox conditions (Wignall and Newton, 1998 and Bond and Wignall, 2010). Euxinia produces populations of tiny framboids (< 5 $\mu \mathrm{m}$ ) with a narrow size range. In dysoxic environments the framboids are larger and more variable in size $(5-15 \mu \mathrm{m})$. Framboids are rare in oxic environments. The chart shows the distribution of framboids from SEM. Individual points indicate a single framboid in the sample. Lines show minimum, maximum and average size for the framboid population in that sample. Framboid populations are indicated for each large data point where $n>1$. Based on the framboid populations, the Upper Frasnian shows an anoxic to lower dysoxic environment consistent with the Kellwasser Anoxia Event. Framboids are much less abundant in the Famennian part of the section indicating a change to upper dysoxic to oxic environments. Stratigraphy is measured from the base of the Hongguleleng Formation.

Although a black shale facies is not present at the base of the Hongguleleng Formation, the Upper Kellwasser Anoxia Event is manifested as an interval of dysoxic to anoxic conditions in the upper portion of the Zhulumute Formation and the lowermost part of the Hongguleleng Formation below the FrasnianFamennian boundary, with minor, episodic dysoxia occurring as high as $6 \mathrm{~m}$ above the base of the Hongguleleng Formation. Similar fluctuations between dysoxic to anoxic to oxic conditions have also been noted in the Holy Cross Mountains in Poland (Kazmierczak et al., 2012) and at La Serre in France (Bond 
et al., 2004). SEM-EDS data confirm an increase of porous, microbially mediated rather than detrital phosphate during this interval (Fig. 10), which is consistent both with anoxia at the sediment-water interface as well as increases in microbially mediated sedimentation (Soudry, 2000). In addition, the base of the Hongguleleng Formation contains layers of winnowed brachiopod beds and rip up clasts that we interpret as storm or tsunami deposits (Fig. 7). These storm/tsunami deposits are consistent with observations of the Kellwasser Event in other locations (Sandberg et al., 1988, Racki et al., 2002, Bond and Wignall, 2008, Du et al., 2008 and Bond et al., 2013).

\subsection{Productivity proxies and magnetic susceptibility}

Barium and $\mathrm{P}_{2} \mathrm{O}_{5}$ normalized to the average $\mathrm{Al}_{2} \mathrm{O}_{3}$ content (Schmitz et al., 1997) of continental crust (Fig. 9) show increased biological productivity during this interval, which is consistent with previous findings in the Kellwasser interval (Racki et al., 2002). Excess $\mathrm{SiO}_{2}$ is also present in the Hongguleleng Formation, presumably in the form of authigenic quartz silt, as Hongguleleng Formation silts lack luminescence and have similar morphologies to proposed biogenic quartz silts (Schieber et al., 2000) in Devonian black shales. In addition, Hongguleleng Formation sediments contain clay minerals and microbial apatite grain morphologies that are consistent with cyanobacterial mat morphologies or algal spores in those associated with black shales (Kazmierczak et al., 2012), where episodic dysoxia rather than persistent euxinic conditions are indicated. Magnetic susceptibility shows a distinctive negative trend just prior to the FrasnianFamennian boundary which is consistent not only with sea level rise characteristic of the Upper Kellwasser Anoxia Event (Bond and Wignall, 2008 and Da Silva et al., 2009) but also with authigenic magnetite found in suboxic sediments (Karlin et al., 1987), and with the oxidation of pyrite framboids similar to what has been observed in other studies (Suk et al., 1990 and Rowan and Roberts, 2006).

\section{CONCLUSIONS}

Detailed sampling in the uppermost $1 \mathrm{~m}$ of the Zhulumute Formation and basal 6 $\mathrm{m}$ of the Hongguleleng Formation at the Boulongour Reservoir section provides a unique look at the Upper Kellwasser Anoxia Event, the Frasnian-Famennian extinction event and the rebound of shallow marine ecosystems in the Early Famennian. Although black shales are missing, we recognize the Upper Kellwasser Anoxia Event through multiple proxies. Whole rock geochemical analyses, the presence and distribution of pyrite framboids, and the presence of microbial apatite formation support a model of fluctuating anoxic, dysoxic and oxic conditions and enhanced surface productivity, while a $2 \%$ positive $\delta 13 \mathrm{C}$ excursion is consistent with isotope signatures of the Kellwasser Events in other studies. Authigenic quartz silt provides additional support for enhanced surface 
productivity with intermittent anoxia. Magnetic susceptibility data are consistent with a sea level rise through the interval.

For the first time, the Kellwasser Anoxia Event has been documented (1) in shallow water and (2) in an open oceanic setting. Although episodic shallow water anoxia during the Kellwasser Anoxia Event has been observed in previous studies (Bond et al., 2004 and Bond et al., 2013), the Hongguleleng and Zhulumute Formations were deposited in a tectonic setting very different from any of the other locations where the Kellwasser Event has previously been described. Regional tectonic studies, local stratigraphy, sedimentary petrology, and sedimentary $\mathrm{Th} / \mathrm{U}$ ratios all indicate that the sequence was deposited on a steep slope island arc complex in an open oceanic system, similar to the Marianas Islands. Therefore, our work indicates that the Kellwasser Anoxia Event was oceanic in extent, and not an exclusively epicontinental or basinal phenomenon as previous workers have hypothesized.

Our observations are inconsistent with the models of deep water spillover onto continental shelves during sea level rise (McGhee, 1996) or local oceanic overturning (Chen et al., 2013) as causal mechanisms for the Kellwasser Anoxia Event. If this were the case, our new data would imply a complete overturning of the oceanic water mass (a highly unlikely scenario) in order to preserve anoxia signals in an open ocean environment. Likewise, invoking sea level rise as a causal mechanism for anoxia (Bond et al., 2004) is an equally unlikely scenario, as transgressions are not uniformly associated with ocean anoxia events (Becker et al., 2012). A revised model (Fig. 12) that supports other published studies of the Kellwasser Anoxia Event involves episodic dysoxia due to eutrophication and enhanced surface productivity (consistent with work by Murphy et al., 2000 and Kazmierczak et al., 2012), and results not only in water column stagnation and stratification in epicontinental basins (Bond et al., 2004 and Chen et al., 2013) and episodic dysoxia in shallow water reefs on continental shelves (Bond et al., 2013), but also in episodic dysoxia in shallow waters along steep island arc margins in the open ocean (this study). 


\section{Surface hypoxia due to coastal eutrophication or high plankton production}
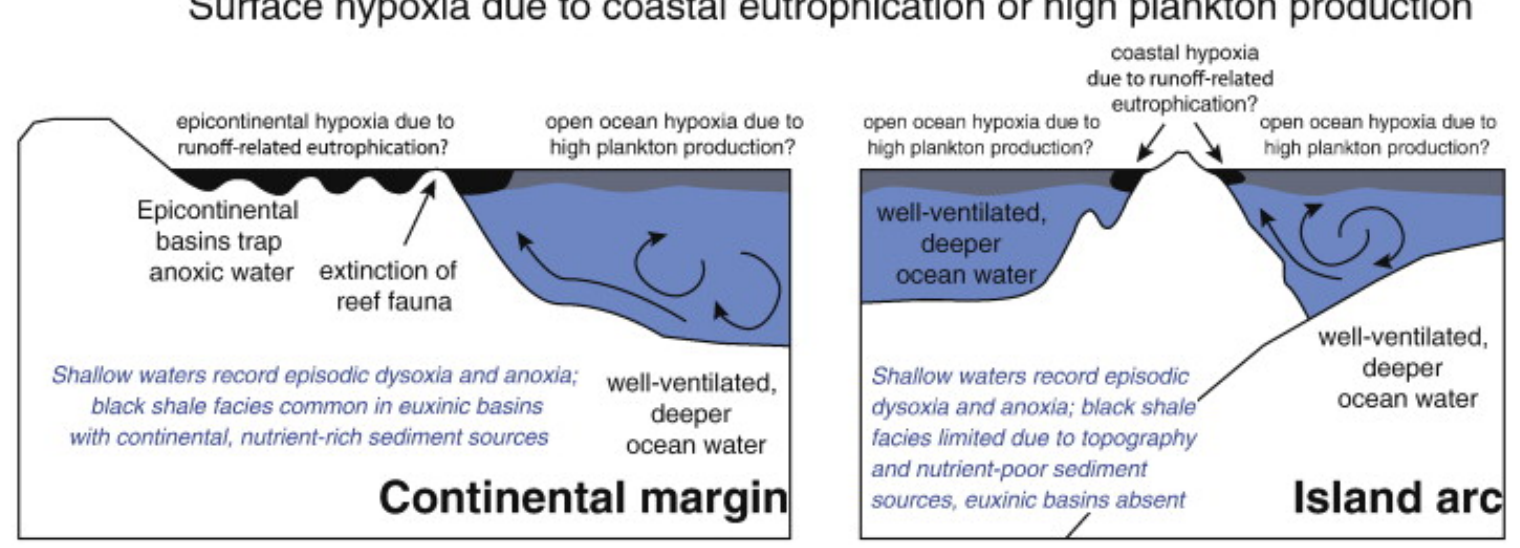

Fig. 12.

New model for the Kellwasser Events invoking eutrophication and enhanced surface productivity as a causal mechanism for episodic dysoxia and sustained anoxia, both along continental shelves (model modified from Bond et al., 2004), and along island arc coastlines in the open ocean (model modified from a topographic transect across the Marianas Islands, commonly used as a modern analogue for the Late Devonian tectonic setting of the Hongguleleng Formation).

This new model is consistent with observations of modern coastal eutrophication in shallow and deep waters along both continental margins and oceanic islands (McGlathery et al., 2007 and Diaz and Rosenberg, 2008). These present-day observations explain coastal eutrophication via local nutrient availability, which causes enhanced primary productivity. Modern hypoxia varies widely in time and space from deep water euxinia in restricted basins to ephemeral dysoxia in shallow coastal bays, lagoons and estuaries. Our new model explains the documented occurrences of the Kellwasser Events both in shallow epicontinental shelf and deep basin environments, but also explains the presence of episodic dysoxia in open oceanic systems such as the one described here in the CAOB. This model can be tested by additional field and geochemical studies in other island arc and microcontinental accretionary systems such as those preserved in the $\mathrm{CAOB}$ and similar tectonic regimes.

\section{Acknowledgments}

Field work in 2005-2012 was supported by the following individuals in addition to the authors: X. Q. Chen, Ruth Mawson, John A. Talent, J. Fryda, D. Mathieson, J. Pickett, Gary D. Webster, and B. Frydova. X. Q. Chen is especially thanked for coordinating field trips and for handling the visa process. S. Sanchez assisted with microscopy. Carmichael was supported by NC Space Grant. Waters was supported by the Assembling the Echinoderm Tree of Life Project (DEB1314236), a Temminck Fellowship to the Naturalis Biodiversity Center, Leiden, and Appalachian State University. Kido and Suttner were supported by NAP0001 (subproject of IGCP 497) and NAP0017 (subproject of IGCP 580). DeReuil was 
supported through Appalachian State University. This paper is a contribution to IGCP Project 596, Climate Change and Biodiversity Patterns in the MidPalaeozoic. The authors are grateful to two anonymous reviewers who provided helpful comments on the manuscript.

\section{References}

Algeo, T.J., Lyons, T.W., 2006. Mo-total organic carbon covariation in modern anoxic marine environments: Implications for analysis of paleoredox and paleohydrographic conditions. Paleoceanography 21.

Algeo, T.J., Maynard, J.B., 2004. Trace-element behavior and redox facies in core shales of Upper Pennsylvanian Kansas-type cyclothems. Chemical Geology 206, 289-318.

Algeo, T.J., Scheckler, S.E., 1998. Terrestrial-marine teleconnections in the Devonian: links between the evolution of land plants, weathering processes, and marine anoxic events. Philosophical Transactions of the Royal Society of London. Series B: Biological Sciences 353, 113-130.

Bambach, R.K., Knoll, A.H., Wang, S.C., 2004. Origination, extinction, and mass depletions of marine diversity. Paleobiology 30, 522-542.

Becker, R., Gradstein, F., Hammer, O., 2012. The Devonian period, in: Gradstein, F.M., Ogg, J.G., Schmitz, M., Ogg, G. (Eds.), The Geologic Time Scale 2012. Elsevier, Amsterdam, pp. 559-601.

Blakey, R., 2008. Late Devonian Paleogeography. Colorado Plateau Geosystems, Inc. Bond, D., Wignall, P.B., 2005. Evidence for late Devonian (Kellwasser) anoxic events in the Great Basin, western United States. Developments in Palaeontology and Stratigraphy 20, 225- 262.

Bond, D., Wignall, P.B., Racki, G., 2004. Extent and duration of marine anoxia during the Frasnian-Famennian (Late Devonian) mass extinction in Poland, Germany, Austria and France. Geological Magazine 141, 173-193.

Bond, D.P., Wignall, P.B., 2008. The role of sea-level change and marine anoxia in the Frasnian-Famennian (Late Devonian) mass extinction. Palaeogeography, Palaeoclimatology, Palaeoecology 263, 107-118.

Bond, D.P., Wignall, P.B., 2010. Pyrite framboid study of marine PermianTriassic boundary sections: a complex anoxic event and its relationship to contemporaneous mass extinction. Geological Society of America Bulletin 122, 1265-1279. 
Bond, D.P., Zatoń, M., Wignall, P.B., Marynowski, L., 2013. Evidence for shallowwater 'Upper Kellwasser'anoxia in the Frasnian-Famennian reefs of Alberta, Canada. Lethaia 46, 355-368.

Buggisch, W., Joachimski, M.M., 2006. Carbon isotope stratigraphy of the Devonian of Central and Southern Europe. Palaeogeography, Palaeoclimatology, Palaeoecology 240, 68-88.

Carmichael, S.K., Ferry, J.M., 2008. Formation of replacement dolomite in the Latemar carbonate buildup, Dolomites, northern Italy: Part 2. Origin of the dolomitizing fluid and the amount and duration of fluid flow. American Journal of Science 308, 885-904.

Carpentier, M., Weis, D., Chauvel, C., 2013. Large U loss during weathering of upper continental crust: The sedimentary record. Chemical Geology 340, 91104.

Chaudhuri, S.K., Lack, J.G., Coates, J.D., 2001. Biogenic Magnetite Formation through Anaerobic Biooxidation of Fe(II). Applied and Environmental Microbiology 67, 2844-2848.

Chen, D., Tucker, M., Shen, Y., Yans, J., Preat, A., 2002. Carbon isotope excursions and sea- level change: implications for the Frasnian-Famennian biotic crisis. Journal of the Geological Society 159, 623-626.

Chen, D., Wang, J., Racki, G., Li, H., Wang, C., Ma, X., Whalen, M.T., 2013. Large sulphur isotopic perturbations and oceanic changes during the FrasnianFamennian transition of the Late Devonian. Journal of the Geological Society 170, 465-476.

Choulet, F., Faure, M., Cluzel, D., Chen, Y., Lin, W., Wang, B., Jahn, B.-M., 2012. Architecture and evolution of accretionary orogens in the Altaids collage: The early Paleozoic West Junggar (NW China). American Journal of Science $312,1098-1145$.

Copper, P., 2002. Reef development at the Frasnian/Famennian mass extinction boundary. Palaeogeography, Palaeoclimatology, Palaeoecology 181, 2765. Copper, P., Scotese, C.R., 2003. Megareefs in Middle Devonian supergreenhouse climates. Geological Society of America - Special Papers 370, 209-230.

Da Silva, A., Mabille, C., Boulvain, F., 2009. Influence of sedimentary setting on the use of magnetic susceptibility: examples from the Devonian of Belgium. Sedimentology 56, 1292- 1306. Diaz, R.J., Rosenberg, R., 2008. Spreading dead zones and consequences for marine ecosystems. Science 321, 926-929. 
Du, Y., Gong, Y., Zeng, X., Huang, H., Yang, J., Zhang, Z., Huang, Z., 2008. Devonian Frasnian-Famennian transitional event deposits of Guangxi, South China and their possible tsunami origin. Science in China Series D: Earth Sciences 51, 1570-1580.

Joachimski, M., Pancost, R., Freeman, K., Ostertag-Henning, C., Buggisch, W., 2002. Carbon isotope geochemistry of the Frasnian-Famennian transition.

Palaeogeography, Palaeoclimatology, Palaeoecology 181, 91-109.

Joachimski, M.M., Buggisch, W., 1993. Anoxic events in the late FrasnianCauses of the Frasnian-Famennian faunal crisis? Geology 21, 675-678.

Kaiho, K., Yatsu, S., Oba, M., Gorjan, P., Casier, J.-G., Ikeda, M., 2013. A forest fire and soil erosion event during the Late Devonian mass extinction, Palaeogeography, Palaeoclimatology, Palaeoecology.

Karlin, R., Lyle, M., Heath, G.R., 1987. Authigenic magnetite formation in suboxic marine sediments. Nature 326, 490-493.

Kazmierczak, J., Kremer, B., Racki, G., 2012. Late Devonian marine anoxia challenged by benthic cyanobacterial mats. Geobiology 10, 371-383.

Lane, N.G., Waters, J.A., Maples, C.G., 1997. Echinoderm faunas of the Hongguleleng Formation, Late Devonian (Famennian), Xinjiang-Uygur Autonomous Region, People's Republic of China. Memoir (The Paleontological Society), 1-43.

Ma, X.P., Zong, P., Sun, Y.L., 2011. The Devonian (Famennian) sequence in the western Junggar area, Northern Xinjiang, China. SDS Newsletter 26, 4449. McGhee, G.R., 1996. The late Devonian mass extinction: the Frasnian/Famennian crisis. Columbia University Press.

McGhee, G.R., Clapham, M.E., Sheehan, P.M., Bottjer, D.J., Droser, M.L., 2013. A new ecological-severity ranking of major Phanerozoic biodiversity crises.

Palaeogeography, Palaeoclimatology, Palaeoecology 370, 260-270.

McGlathery, K.J., Sundback, K., Anderson, I.C., 2007. Eutrophication in shallow coastal bays and lagoons: the role of plants in the coastal filter. Marine Ecology Progress Series 348, 1-18.

Murphy, A.E., Sageman, B.B., Hollander, D.J., 2000. Eutrophication by decoupling of the marine biogeochemical cycles of $\mathrm{C}, \mathrm{N}$, and $\mathrm{P}$ : A mechanism for the Late Devonian mass extinction. Geology 28, 427-430. 
Pujol, F., Berner, Z., Stüben, D., 2006. Palaeoenvironmental changes at the Frasnian/Famennian boundary in key European sections: Chemostratigraphic constraints. Palaeogeography, Palaeoclimatology, Palaeoecology 240, $120-$ 145. Racki, G., 2005. Toward understanding Late Devonian global events: few answers, many questions, in: Over, D.J., Morrow, J.R., Wignall, P.B. (Eds.), Understanding Late Devonian and Permian-Triassic Biotic and Climatic Events: Towards an Integrated Approach, pp. 5-36.

Racki, G., Racka, M., Matyja, H., Devleeschouwer, X., 2002. The Frasnian/Famennian boundary interval in the South Polish-Moravian shelf basins: integrated event-stratigraphical approach. Palaeogeography, Palaeoclimatology, Palaeoecology 181, 251-297.

Rowan, C.J., Roberts, A.P., 2006. Magnetite dissolution, diachronous greigite formation, and secondary magnetizations from pyrite oxidation: Unravelling complex magnetizations in Neogene marine sediments from New Zealand. Earth and Planetary Science Letters 241, 119- 137.

Royer, D.L., 2006. CO2-forced climate thresholds during the Phanerozoic. Geochimica et Cosmochimica Acta 70, 5665-5675.

Sandberg, C.A., Ziegler, W., Dreesen, R., Butler, J.L., 1988. Late Frasnian mass extinction: conodont event stratigraphy, global changes, and possible causes. Courier Forschungsinstitut Senckenberg 102, 263-307.

Schieber, J., Krinsley, D., Riciputi, L., 2000. Diagenetic origin of quartz silt in mudstones and implications for silica cycling. Nature 406, 981-985.

Schmitz, B., Charisi, S.D., Thompson, E.I., Speijer, R.P., 1997. Barium, SiO2 (excess), and $\mathrm{P} 2 \mathrm{O} 5$ as proxies of biological productivity in the Middle East during the Palaeocene and the latest Palaeocene benthic extinction event. Terra Nova 9, 95-99.

Schröder, S., Grotzinger, J., 2007. Evidence for anoxia at the EdiacaranCambrian boundary: the record of redox-sensitive trace elements and rare earth elements in Oman. Journal of the Geological Society 164, 175-187.

Sepkoski, J.J., 1996. Patterns of Phanerozoic extinction: a perspective from global data bases, in: Walliser, O.H. (Ed.), Global events and event stratigraphy in the Phanerozoic. Springer-Verlag, Berlin, Berlin, pp. 35-51.

Soudry, D., 2000. Microbial phosphate sediment. Microbial Sediments, 127136. Stigall, A.L., 2012. Speciation collapse and invasive species dynamics during the Late Devonian "Mass Extinction". GSA Today 22, 4-9.

Suk, D., Peacor, D., Van der Voo, R., 1990. Replacement of pyrite framboids by magnetite in limestone and implications for palaeomagnetism. Nature 345, 611613. 
Suttner, T.J., Kido, E., Chen, X., Mawson, R., Waters, J.A., Frýda, J., Mathieson, D., Molloy, P.D., Pickett, J., Webster, G.D., Frýdová, B., 2014. Stratigraphy and facies development of the marine Late Devonian near the Boulongour Reservoir, northwest Xinjiang, China. Journal of Asian Earth Sciences 80, 101-118.

Tribovillard, N., Algeo, T.J., Lyons, T., Riboulleau, A., 2006. Trace metals as paleoredox and paleoproductivity proxies: An update. Chemical Geology 232, 1232.

Tribovillard, N., Averbuch, O., Devleeschouwer, X., Racki, G., Riboulleau, A., 2004. Deep-water anoxia over the Frasnian-Famennian boundary (La Serre, France): a tectonically induced oceanic anoxic event? Terra Nova 16, 288-295.

Wignall, P., Newton, R., 1998. Pyrite framboid diameter as a measure of oxygen deficiency in ancient mudrocks. American Journal of Science 298, 537-552.

Wignall, P.B., Myers, K.J., 1988. Interpreting benthic oxygen levels in mudrocks: a new approach. Geology 16, 452-455.

Wilkin, R., Barnes, H., Brantley, S., 1996. The size distribution of framboidal pyrite in modern sediments: An indicator of redox conditions. Geochimica et Cosmochimica Acta 60, 3897-3912.

Wright, J., Schrader, H., Holser, W.T., 1987. Paleoredox variations in ancient oceans recorded by rare earth elements in fossil apatite. Geochimica et Cosmochimica Acta 51, 631-644.

Xia, F., 1997. Marine microfaunas (bryozoans, conodonts and microvertebrate remains) from the Frasnian-Famennian interval in northwestern Junggar Basin of Xinjiang in China. Beiträge zur Paläontologie 22, 91-207.

Xiao, W., Huang, B., Han, C., Sun, S., Li, J., 2010. A review of the western part of the Altaids: a key to understanding the architecture of accretionary orogens. Gondwana Research 18, 253-273.

Yang, G., Li, Y., Santosh, M., Yang, B., Zhang, B., Tong, L., 2013. Geochronology and geochemistry of basalts from the Karamay ophiolitic mélange in West Junggar (NW China): Implications for Devonian-Carboniferous intra-oceanic accretionary tectonics of the southern Altaids. Geological Society of America Bulletin 125, 401-419. 